Article

\title{
Beyond the Cosmopolis: Sustaining Hyper-Diversity in the Suburbs of Peel Region, Ontario
}

\author{
Jennifer Dean ${ }^{1, *}$, Kristen Regier ${ }^{1}$, Asiya Patel ${ }^{1}$, Kathi Wilson ${ }^{2}$ and Effat Ghassemi ${ }^{3}$ \\ ${ }^{1}$ School of Planning, University of Waterloo, Waterloo, ON N2L 3G1, Canada; E-Mails: jennifer.dean@uwaterloo.ca (J.D.), \\ kvreiger@edu.uwaterloo.ca (K.R.), asiya.patel@edu.uwaterloo.ca (A.P.) \\ 2 Department of Geography, University of Toronto, Mississauga, ON L5L 1C6, Canada; E-Mail: kathi.wilson@utoronto.ca \\ ${ }^{3}$ Newcomer Centre of Peel, Mississauga, ON L5B 2N6, Canada; E-Mail: eghassemi@ncpeel.ca \\ * Corresponding author
}

Submitted: 17 July 2018 | Accepted: 17 September 2018 | Published: 30 October 2018

\begin{abstract}
Globalization has increased the flow of transnational migrants into many European and North American cities. These shifting socio-demographic patterns have resulted in the rapid development of 'cosmopolitan' urban centres where difference and diversity are ubiquitous (Sandercock, 2003). However, as ethnic enclaves form outside the urban core in suburban communities, there is uncertainty about whether cultural homogeneity is desirable or sustainable in a multicultural country. Indeed, planning communities for increasing diversity and difference will remain, what Leonie Sandercock (2004) calls, "one of the greatest tasks for planners of the 21st century". Thus, this article uses the theory of hyper-diversity to illuminate how immigrants' interactions with their local suburban community represents cultural pluralism and diversity beyond ethnicity. Specifically, this study explores differing attitudes, activities and lifestyles among diverse immigrant populations in the Region of Peel, one of the fastest growing and most culturally diverse areas in Canada. Focus groups with $60 \mathrm{immigrant}$ youth and 55 immigrant adults were conducted to qualitatively capture perspectives and experiences in ethnic enclaves. The findings highlight the existence of attitudes in favor of multicultural lifestyles, activities that take newcomers beyond the borders of their enclaves, and lifestyles that require additional infrastructure to support sustainability of immigration in the suburbs. In conclusion, this article adds to the debate on cultural pluralism and 'homogeneous' ethnic enclaves by using the emergent concept of hyper-diversity as a way to think about the future sustainability of suburbs in an era of global migration.
\end{abstract}

\section{Keywords}

belonging; hyper-diversity; immigration; inclusion; social planning; suburbs

\section{Issue}

This article is part of the issue "Urban Planning and the Suburbs: Solutions for Sustainability from the Edges", edited by Markus Moos (University of Waterloo, Canada).

(C) 2018 by the authors; licensee Cogitatio (Lisbon, Portugal). This article is licensed under a Creative Commons Attribution 4.0 International License (CC BY).

\section{Introduction}

Globalization has increased the flow and diversity of transnational migrants into many European and North American cities (Castles, de Haas, \& Miller, 2013). In Canada, immigrants currently account for $22 \%$ of the total population and are expected to be the nation's solesource of population growth by 2040 (Statistics Canada, 2017a). The vast majority of these immigrants continue to make urban centres their destination of choice with over two-thirds first settling in the three largest cities of Montreal, Vancouver and Toronto (Statistics Canada, 2017b). These transnational migration patterns coupled with 'planetary urbanization' (Brenner, 2014) have resulted in the rapid development of 'cosmopolitan' urban centres where difference and diversity are ubiquitous 
(Sandercock, 2003). In fact, the rapid ethnic diversification of many European cities is evidence that we are now in an era of 'super-diversity' (Vertovec, 2007). Planning communities for this increasing diversity is what planning scholar Leonie Sandercock (2004) calls, 'one of the greatest tasks for planners of the 21st century'. More than a decade later, Sandercock's statement seems rather foreboding as anti-immigration and post-multicultural political events in the USA and Europe make headlines.

Despite the centrality of urban spaces in much of the above literature, the reality is that diversity is actually increasing in the suburbs across Canada (Addie, Fiedler, \& Keil, 2015; Qadeer, Agrawal, \& Lovell, 2010). Recent Canadian Census data indicates that among the $63 \%$ of newcomers who settle in the Toronto Census Metropolitan Area, over half were in suburban municipalities. This is a $10 \%$ increase from the past decade (Statistics Canada, 2017b). Similarly, the suburbanization rate of immigrants is increasing in Montreal (up 5\% to $33 \%$ ) and Vancouver (up $8 \%$ to $72 \%$; Statistics Canada, 2017b). These trends are not unique to Canada; the majority of US immigrants (61\%) live in suburbs (Wilson \& Singer, 2011), and as a result have dramatically shaped the social, political, physical and cultural landscapes of the suburbs within the United States (Hanlon, Vicino, \& Short, 2006; Johnson, 2015; Lung-Amam, 2017; Singer, Hardwick, \& Brettell, 2008; Vicino, 2013). In their work in Amsterdam, Tzaninis and Boterman (2018, p. 46) suggest that suburbs are "increasingly entry points for international migrants, pointing towards the consistent manifestation of suburban multicultural spaces". This supports claims that the rapid urbanization of the 21st century will actually occur on the peripheries of urban centres, creating what Keil (2018) calls a 'suburban planet'.

In this article, we aim to explore social diversity in an era of global migration and suburbanization in order to provide a new lens through which to tackle the century problem Sandercock warns us of. Indeed, the reality of growing suburban settlement of ethnically diverse immigrants seems incongruent with the dominant (and persistent) narratives of suburban landscapes as socially homogeneous and physically isolating (Forsyth, 2012; Hanlon et al., 2006; Keil, 2018; Walks, 2013). This article interrogates literature on social diversity in the suburbs and builds on theories of planning for diversity by considering how to interpret new forms of diversity outside of cosmopolitan cities. In light of the projected and required rise in immigration, planning suburban communities that can socially sustain Canada's diverse populations of today and the future is a crucial priority.

\subsection{Beyond Cosmopolis: Social Diversity in the Suburbs}

Our understanding of the suburbs has changed significantly since the term was first introduced in the midtwentieth century (Fava, 1956). The suburban prototype of the late 1940s was indeed socially and economically homogeneous. Fava's original notion was that suburbs were 'a way of life' among the largely young, middleclass, married families with children who valued the privacy of detached homes and supported the sense of neighbourliness and social cohesion that the suburbs were designed to create (Fava, 1956, p. 34). Retrospective work on the suburbs argued that it was the lack of cohesion, plurality, interaction and co-existence that came to dominate the narrative of the suburban experience (see Nicolaides \& Weise, 2006, in Forsyth, 2012). While the North American suburbs of today have been cast in the same light as their 1940s predecessor, the reality is quite the opposite. The North American suburbs of the past half century have increasingly become places of socio-cultural, economic, and political diversity (Forsyth, 2012; Hanlon et al., 2006; Walks, 2013). Appropriately, there is no longer a singular definition of what constitutes a suburb, rather a recognition of a range of global suburbanisms (Keil, 2018; Walks, 2013) that vary by physical, social, functional and other dimensions (Forsyth, 2012; Walks, 2013).

Although several suburban scholars reject that a homogeneous suburb ever existed (Forsyth, 2012; Harris, 2015; Keil, 2018; Walks, 2013), the notion of sociocultural and ethnic clustering outside urban core sparked the focus on 'ethnoburbs' (Li, 1998, 2009). Geographer Wei Li (1998) first introduced the term ethnoburb 20 years ago, when she described the prevalence of suburban clusters of ethnic minorities that form outside of major metropolitan areas. These communities offer ethno-cultural amenities that support a sense of community including places of worship, shopping centres and other services such as ethnic businesses that cater to the ethnic-minority population (Li, 2009; Qadeer, 2016).

These changing settlement patterns contradict the dominant 'spatial assimilation model' of immigrant mobility that suggests that newcomers first settle in innercity neighbourhoods drawn by the housing affordability, employment opportunities and existing concentrations of immigrants (Park, Burgess, \& Mckenzie, 1925). These early ethnic enclaves of the inner-city core were seen as merely 'zones of transition' for newcomer populations who, through the assimilation process, would eventually move into neighbourhoods on the periphery of the city populated by the ethnic majority (Park et al., 1925). More recent waves of immigrants in the USA (Alba, Logan, Stults, Marzan, \& Zhang, 1999; Hanlon et al., 2006; Johnson, 2015; Li, 2009; Lung-Amam, 2017; Singer et al., 2008), Canada (Hiebert, Schuurman, \& Smith, 2007) and New Zealand (Johnston, Gendall, Trlin, \& Spoonley, 2010), have opted to directly settle in existing ethnic enclaves within the suburbs. The 'suburbanization of enclaves' is a result of increased homeownership opportunities, access to emergent job markets and larger dwelling sizes (Qadeer et al., 2010) in comparison to contemporary urban areas where the proliferation of highrise condominiums and soaring house prices have displaced low income residents, including immigrants and ethnic-minorities, to the periphery (Keil, 2018). 


\subsection{Planning for Difference and Hyper-Diversity}

The primary critique of ethnoburbs and the allied political ideology of multiculturalism is that they dissipate 'common ground' or the shared experiences and ideologies that promote national identity (Qadeer, 2016; Tasan-Kok, van Kempen, Raco, \& Bolt, 2014). The rhetoric of immigrants leading 'parallel lives' has been pervasive in political discussions of multiculturalism across the globe. The existence and growth of ethnic enclaves are often used as evidence of the self-segregation patterns of more recent waves of immigrants and ethnic-minorities (Tyler, 2017). There has been a significant body of urban research over the past decade examining the settings of inter-group encounters and whether segregated ethnic-minority communities erode social cohesion and national identity (Costa \& Kahn, 2003; Piekut \& Valentine, 2017; Pratsinakis, Hatziprokopiou, Labrianidis, \& Vogiatzis, 2017; Putnam, 2007; Tyler, 2017). These debates have been obvious in planning literature through the focus on social mix (Arthurson, 2012; Bacqué, Fijalkow, Launay, \& Vermeersch, 2011) and the promotion of cultural pluralism as a way to integrate difference and build a sense of community (Qadeer, 2016; Talen, 2008). The concept of ethnic enclaves as relatively homogeneous spaces would then appear to be neither supportive of social cohesion nor sustainable in an era of increasing ethno-cultural diversity. Thus far, this widespread assumption has been challenged using two arguments about exposure to diversity for residents of ethnic enclaves.

The first position argues that the relative homogeneity of an enclave is irrelevant to concerns about social cohesion due to the level of diversity that exists outside the enclave. For instance, Qadeer's (2016) work on multiculturalism in Toronto, Los Angeles and New York concludes that the vast majority of residents leave their local community to access health and social services and attend school or work. In an era of super-diversity, encountering difference and learning national values happens beyond neighbourhood boundaries through major institutions and mass media (Qadeer \& Kumar, 2006). This is akin to Werbner's (2013) concept of 'everyday multiculturalism' that "works as a cohesive force which resists and transcends fragmentation and division" (Pratsinakis et al., 2017, p. 104). This position thus laments that diversity within an ethnoburb is not required in order to encounter difference and appreciate national values.

The second argument posits that diversity does, in fact, exist within ethnic enclaves. Historically, enclaves in the Greater Toronto Area (GTA) have been secondary in nature, meaning the largest ethnic-minority population did not exceed $50 \%$ of the total population, which implies that ethnic heterogeneity exists within the space (Qadeer et al., 2010). Further, enclaves have additional forms of internal diversity beyond ethnicity that are based on residents' gender, age, migration status and sexuality among other characteristics (Qadeer et al., 2010; Li, 2005; Pitter \& Lorinc, 2016).
The rhetoric of parallel lives, however, has persisted. In 2016, ethnic-minority concentrations had intensified in GTA suburbs resulting in the rise of primary enclaves where one ethnic group comprises the majority of the population (Qadeer \& Agrawal, 2018). This sparked widespread concern over the social changes and new homogeneity in these communities as is made evident by the tone of media coverage, such as: "Brampton suffers identity crisis as newcomers swell city's population" (Grewal, 2013) and "How Brampton, a town in suburban Ontario, was dubbed a ghetto" (Ahmed-Ullah, 2017). With this rise in arguments against demographic change and homogeneous suburbs, comes wider concerns about the desirablity of ethnic enclaves in an era of super-diversity and multiculturalism.

This article contributes to the debate over social cohesion and ethnic enclaves by offering an alternative reading of diversity. Specifically, we align with scholars who look beyond ethno-cultural differences prominent in 'super-diversity' analyses, citing them as too simplistic to capture the reality of socio-spatial interactions (Kraftl, Bolt, \& Van Kempen, 2018). Rather, we take up the concept of 'hyper-diversity' defined as "an intense diversification of the population in socio-economic, social and ethnic terms, but also with respect to lifestyles, attitudes and activities" (Tasan-Kok et al., 2014, p. 6). This emerging concept is increasingly used to understand aspects beyond represented identities such as gender, age and ethnicity, in addition to everyday behaviours, sub/urban lifestyles, and performances in/of place (i.e., non-representational), that influence life in multicultural contexts. For instance, a recent special issue of Social \& Cultural Geography used hyper-diversity as concept to "push at the boundaries of definitions of 'super-diversity'" by challenging its common use "in ways that are fairly static, as uncontested (even a-political) matters of fact" (Kraftl et al., 2018). Hyper-diversity then, can be used to understand how hyper-diverse spaces are experienced 'on the ground' (Peterson, 2017), as well as how non-representational aspects of being also contribute to the diversity of spaces (Wilkinson, 2018). To date, the concept of hyper-diversity has not been applied in Canada's multicultural context (but see Pitter \& Lorinc, 2016) nor has it been used to interpret the existence and realities of ethnic enclaves.

The objective of this article is twofold. First, we critique existing notions of suburban ethnoburbs as homogeneous spaces that limit opportunities for encountering difference and inhibit social cohesion. Secondly, we use a hyper-diversity lens to examine non-representational aspects of diversity that influence immigrant populations living in ethnoburbs. To these ends, we analyze qualitative data from immigrants settling in one of Canada's most diverse suburban regions and conclude by recommending how the urban planning profession can create inclusive suburban spaces that sustain future hyperdiverse populations. 


\section{Research Design and Methods}

This exploratory study was part of a larger qualitative project that examined social inclusion, settlement and integration experiences of newcomers in Peel Region, Ontario, Canada, which is part of the GTA.

There is ample evidence of the increasing suburbanization of immigrants in the GTA and the growing presence of primary and secondary ethnic enclaves (see Figure 1). A recent study highlights that the 'territorial sectoralization' of most visible minority enclaves has increased between 2006 and 2016, and ethnic-minority enclaves exist almost exclusively outside the urban core of Toronto (Qadeer \& Agrawal, 2018). This is due in large part to the relative affordability and suitability of larger single-detached homes in new developments that make these neighbourhoods attractive to newcomer families (Qadeer \& Agrawal, 2018; Qadeer \& Kumar, 2006). In the Cities of Brampton and Markham, for example, most of the ethnic enclaves are on former greenfield sites that have been developed over the past three decades. The predominantly South Asian and Chinese immigrant populations have been major drivers of the population growth in these areas, and the clustering of these groups has resulted in communities with ethnic economies, urban services, and land-uses tailored to these populations.

The Region of Peel is a large regional municipality located directly west of Toronto, Canada. It is comprised of three municipalities, the Town of Caledon, the City of Brampton, and the City of Mississauga. As of 2016, the Region of Peel is home to nearly 1.4 million people (Statistics Canada, 2017a). Overall, the Region is rapidly growing and increasingly diverse; it is acknowledged as one of the most diverse regions in Canada (Bascaramurty, 2013; Pitter \& Lorinc, 2016). This diversity is exemplified by the fact that $51.5 \%$ of the Region's population is comprised of immigrants, and $62.3 \%$ of the total population are visible minorities. The City of Brampton has even higher rates, with $73.3 \%$ visible minorities and certain neighbourhoods containing above $90 \%$ (Statistics Canada, 2017a).

Mississauga is the most urban city within the Region, containing the highest total population $(\sim 722,000)$ and density $\left(2,467.6\right.$ people per $\mathrm{km}^{2}$; Statistics Canada, 2017a). With no room for greenfield development, the City has prioritized infill development and now has $78.1 \%$

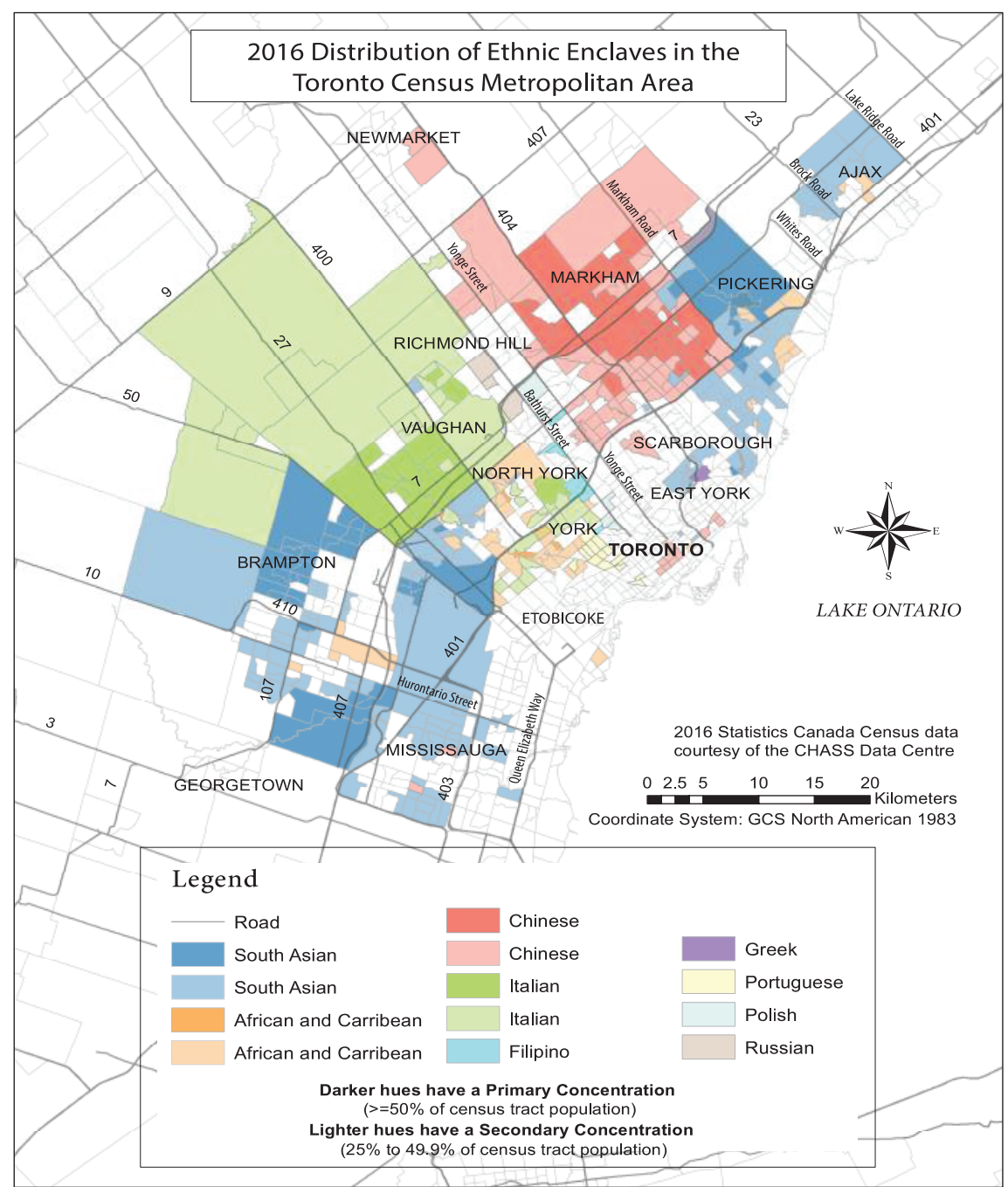

Figure 1. Primary and secondary ethnic enclaves in the GTA (Qadeer \& Agrawal, 2018). 
of Peel's high-rise buildings (Statistics Canada, 2017a). While it is the largest and most dense municipality in the Region, its growth has slowed. The City of Mississauga grew only 1.1\% between 2011-2016 (Statistics Canada, 2017a). Mississauga is home to several distinct ethnic communities including Chinese (13.2\%), Arab (8.8\%) and Filipino (8.9\%).

In contrast, Brampton is a more distinct suburban municipality with a growing population $(\sim 594,000)$ evidenced by $36.8 \%$ positive growth between 2011-2016 (Statistics Canada, 2017a). Compared to Mississauga, Brampton is more sprawled with an average population density of 2,228.7 people per $\mathrm{km}^{2}$, and the majority $(52.1 \%)$ of its housing stock comprised of singledetached dwellings (Statistics Canada, 2017a). Brampton has many ethnic communities within its borders but is widely known as a large South Asian ethnoburb, due to the prominence of the South Asian population ( $44.3 \%$ of the total) and the plethora of places of worship, shops and services that cater to the South Asian community. These trends are reflected in the unofficial renaming of Brampton to 'Bramladesh' and the Springdale neighbourhood to 'Singhdale'.

As part of a collaborative community engaged research project (Van de Ven, 2007), we gathered information about immigrants' broad perceptions and experiences of settlement, integration and inclusion in Peel Region. In total, there were 115 participants who took part in one of 11 focus groups across the Region. Our sample included both youth and adult immigrants from 31 different countries, most of whom had recently arrived in Canada (less than 5 years in the country) and who were part of sponsorship or skilled worked immigration categories. For participant details see Table 1.

Participants were recruited primarily with the assistance of Settlement Service Providers (SSPs) within the Region of Peel who circulated recruitment flyers and offered space on-site for data collection. Community research assistants from SSPs were hired to recruit potential participants and, in few cases, acted as interpreters during focus groups. Other recruitment strategies included information booths and the posting of flyers at community centres and local libraries. Locations were chosen strategically to recruit youth who attended nearby high schools, or adults who frequented libraries. At these venues, information booths were set up where potential participants were informed about the research including where and when the focus group would be conducted. Participants received a $\$ 15$ gift card as an honorarium for their time in the 60-90-minute focus group. This research study was approved by the University of Toronto Research Ethics Board.

The focus groups were audio recorded and then transcribed verbatim. Data for this study were analyzed using Corbin and Strauss' (2014) tripartite coding process. After completing open coding of the 11 focus group transcripts, data on settlement choices and experiences in Peel's suburbs were connected using the axial coding strategy. The final analysis phase used selective coding (Corbin \& Strauss, 2014) to identify three interconnected examples of hyper-diversity.

\section{Immigrants and Hyper-Diversity in the Suburbs}

We theoretically and empirically critique the presumption of ethnic enclaves as homogeneous spaces based on empirical evidence from our qualitative data. Our sample was diverse in many ways including gender, ethnicity, age and migration history (see Table 1) but our findings also suggest that non-representational aspects of being - the attitudes, lifestyles and behaviours of our newcomer participants-are important yet overlooked examples of diversity in the suburbs. In this section, we focus on ways in which the settlement experiences in Peel ethnoburbs can be read through a lens of hyperdiversity that highlights the differing attitudes and activities of immigrants in the suburbs.

\subsection{Constructing Ethnic Enclaves}

In this section, we challenge the fundamental premise underlying the 'problem' with ethnic enclaves: that spatial segregation of homogeneous populations interferes with ideals of cultural pluralism and integration. Ethnic enclaves are defined based on the perception of a common ethnic background of inhabitants; however, the measurement of ethnic enclaves is based on categories of ethnicity constructed for administrative convenience. This is particularly concerning in the case of Brampton's enclaves where South Asians are both the majority-minority in the city while also comprising the majority of the total population in some neighbourhoods (Statistics Canada, 2017a). Constructions of 'South Asian' as a homogeneous ethno-cultural category-or even a well-defined world region-is inherently problematic as argued by geographer Sutama Ghosh (2013). Ghosh highlights that the term was institutionalized by the Canadian government in order to facilitate the collection of immigration and census data from a group of non-white immigrants who were physically similar according to the state (Ghosh, 2013). Ghosh (2013, p. 49) concludes: "Given the heterogeneity among and within 'South Asians' - history, politics, society, economy and culture-it is important to question whether there can ever be a 'South Asian' diasporic identity?" This line of reasoning can be extended to the social and spatial construction of an 'ethnoburb'.

Almost a majority of our sample migrated from India, Pakistan and Sri Lanka, countries that are typically included in the South Asian region. Yet, many participants were quick to distinguish themselves from others with the same ethnic category whether by country of origin, city/village of birth or religious-background. Students in particular reacted to the informal labeling of their community as part of 'Bramladesh' and their high school as 'Little India': 
Table 1. Socio-demographic profile of participants.

\begin{tabular}{|c|c|c|}
\hline & Total & Percent of Total (\%) \\
\hline \multicolumn{3}{|l|}{ Population } \\
\hline Total & 115 & $100 \%$ \\
\hline Male & 47 & $40.8 \%$ \\
\hline No answer & 1 & $0.9 \%$ \\
\hline \multicolumn{3}{|l|}{ Age } \\
\hline$>18$ & 42 & $36.5 \%$ \\
\hline $18-24$ & 18 & $15.7 \%$ \\
\hline $25-34$ & 12 & $10.4 \%$ \\
\hline $35-44$ & 26 & $22.6 \%$ \\
\hline $45-54$ & 10 & $8.7 \%$ \\
\hline $55-64$ & 4 & $3.5 \%$ \\
\hline $65+$ & 2 & $1.8 \%$ \\
\hline No answer & 1 & $0.9 \%$ \\
\hline \multicolumn{3}{|l|}{ Country of Birth } \\
\hline India & 34 & $29.6 \%$ \\
\hline Pakistan & 14 & $12.2 \%$ \\
\hline Iraq & 10 & $8.7 \%$ \\
\hline China & 8 & $6.9 \%$ \\
\hline Columbia & 6 & $5.2 \%$ \\
\hline Other & 43 & $37.4 \%$ \\
\hline \multicolumn{3}{|l|}{ Length of Residency in Canada } \\
\hline$<3$ months & 4 & $3.5 \%$ \\
\hline $3-6$ months & 9 & $7.8 \%$ \\
\hline 7-12 months & 15 & $13.0 \%$ \\
\hline $1-2$ years & 32 & $27.8 \%$ \\
\hline $3-5$ years & 41 & $35.7 \%$ \\
\hline $6-9$ years & 6 & $5.2 \%$ \\
\hline$>9$ years & 7 & $6.1 \%$ \\
\hline \multicolumn{3}{|l|}{ Immigration Category } \\
\hline Economic/Skilled Worker Program & 34 & $29.6 \%$ \\
\hline Family/Sponsorship Program & 47 & $40.9 \%$ \\
\hline Temporary Residency (Student Visa, Temporary Worker Program) & 3 & $2.6 \%$ \\
\hline Refugee Program & 5 & $4.3 \%$ \\
\hline Other & 21 & $18.3 \%$ \\
\hline No answer & 5 & $4.3 \%$ \\
\hline
\end{tabular}

I mean, our school is like the goddam United Nations....Yes, students from India [are here], and also [from] other places: the West Indies, Pakistan, Bangladesh, Iraq, Afghanistan...Iran...and probably more places.

Similarly, adult participants from India noted that there was rich cultural heterogeneity in the diaspora. To illustrate, one participant acknowledged the religious differences (and tensions) among other Indian participants in her focus group: "Back home, we would never be together in the same room...She is Muslim and I am Hindu....[Being together] isn't [common]". Thus, the appropriateness of using administratively-defined categories of ethnicity for the study of enclaves ignores the reality of ethno-cultural heterogeneity, and erroneously creates spatial-boundaries around a diverse population in order to illustrate their constructed sameness. This practice demonstrates very little interest in exploring the distinctions within minority populations beyond the fact that they are not the white majority. Here we see that Ghosh's question above is an important one for planning practitioners and scholars who perpetuate the 'othering' of non-white populations in their uncritical use of the 'South Asian' category in discussions of ethnic enclaves. This emphasis on ethnicity overlooks other important sources of difference that exist in the hyper-diverse reality of suburbs.

\subsection{Performing Belonging in/out of Enclaves}

While past research has acknowledged the social and economic benefits of living in enclaves (Li, 2005; Qadeer, 2016; Qadeer \& Kumar, 2006), the rhetoric of parallel 
lives suggests that immigrants make settlement choices based primarily on community social structure (i.e., homogeneity). In this study, participants shared a deep appreciation for both the existence of multiple ethnic enclaves in the GTA and the quality of ethnoburbs in Peel. For instance, many of the South Asian participants who lived in Brampton were "feeling very good about this place...it is much like my home", and especially found the Mandirs and Gurdawaras in Canada to be "very high quality", with other participants feeling positively about their new communities, "roti, sari, even the [eye-brow] threading is here!" Indeed, some participants were content within enclaves and found that Peel ethnoburbs met all their needs. Further, the familiarity with many of the socio-cultural practices and services within enclaves resulted in a strong sense of belonging and feelings of comfort for some participants. However, this common narrative was challenged by the majority of the participants.

Almost all of the youth and about half of the adult participants in this study expressed their reservations about living exclusively among people with similar cultural backgrounds. This group often discussed the desire for a typically 'Canadian experience' of living in multicultural communities:

A lot of people from India, they choose to live in Brampton.... Now I thought if I wish to integrate into Canadian society, I should not go to my own community. Otherwise what is the difference between living in Mississauga or living in Bombay or Karachi? So, I deliberately chose this neighbourhood, it is a very nice neighbourhood, very nice community... we have a wonderful diversity of people from Poland, Ukraine, China, Mississippi, Native Canadians, and only two, three families from India.

Parents spoke about wanting their kids to have the benefits of 'multicultural Canada' right in their community or school, and youth stated that were eager to learn and experience new cultures. In most cases, diversity was described in ethno-cultural terms, and also regularly perceived as homogeneous by participants, though there was some discussion of sexuality, educational background, age, religion, and migration history as desired sources of community diversity.

The dissonance between wanting to live outside of an enclave while simultaneously enjoying the social and economic benefits generated by the existence of those enclaves was neither acknowledged nor reconciled by the participants who held this view. Indeed, this epitomizes the challenge of social integration for immigrants: how to delicately balance the personal ethno-cultural and other representational differences within the private domain, with the desire to be part of the common ground in the shared public domain (e.g., multiculturalism and social mixing; Qadeer, 2016). This is ultimately about belonging and feelings of inclusion (Omidvar \& Richmond, 2003), and how the process of belonging for these newcomers is performed in space (Lung-Amam, 2017). For participants, the desire to live outside of enclaves can be read as performing a 'Canadian lifestyle'. The choice to reside in a multicultural space was a crucial aspect of belonging for these participants. Here we have evidence of hyper-diversity based on participants' performances of belonging, which determined their desire and decision to reside within or outside enclaves.

\subsection{The Role of Networks and Mobilities in Suburban Settlement}

Decisions about where to reside were also largely influenced by the socio-spatial structure of the GTA. Many participants argued that living anywhere in GTA would provide enough access to cultural-specific amenities while also benefiting from the diversity of the region. The frequency and proximity of ethnic enclaves in the GTA, particularly for those of Indian, Pakistani and Sri Lankan descent, and those of Chinese, Korean, and Vietnamese descent, allowed participants to easily frequent enclaves in neighbouring cities (usually by private automobile). Several participants described how they would regularly travel from one ethnoburb to another to attend a religious service, go shopping, or connect with family or friends. This is exemplified by Iris, a Chinese-Korean teenager who migrated with her parents two years ago:

We live here in [Mississauga] and go to Mississauga Chinese Centre, shop at [the Asian supermarket] and go to [Korean church], there are lots of things here for Asians....We still like to go to Markham every weekend and eat at real Korean restaurants and stop at Pacific Mall.... My parents have friends there from back home that we meet with.

Peel was a preferred destination by many participants because of its affordability, proximity to Toronto, and connections to surrounding cities with established or growing enclaves like Markham, Richmond Hill, Milton, and for some Eastern European immigrants, Hamilton. For many participants, the enclave boundaries were fluid and the close proximity to other enclaves encouraged mobility. In this sense, Peel enclaves were not destinations in and of themselves but instead represented nodes in a network of communities in the GTA and beyond.

This finding suggests that we can think of enclaves as not just dynamic spaces (Qadeer et al., 2010) but also as relational spaces (Graham \& Healey, 1999). Such an approach requires us to think beyond the (albeit changing) borders of an enclave towards the fluidity of boundaries, the connectivity of multiple spaces, and the relevance of socio-relational determinants of activity space and mobility. This also supports arguments that residents encounter diversity outside their communities as they are not exclusively bound by the invisible borders of their neighbourhoods. Further, a relational approach to un- 
derstanding space is inherently complementary to a focus on hyper-diversity. For instance, rather than focus on ethnic congregation as a determinant of settlement in the suburbs, we can focus of the role of mobility in a networked region when determining how/why some ethnic minorities move through space during the settlement process. Once again, considering hyper-diversity in this way poses a distinct challenge to the parallel lives narrative commonly used to critique ethnic enclaves and immigrant settlement in segregated communities.

\subsection{Considering Housing Trajectories and Settlement Experiences in the Suburbs}

Immigrants' performance of belonging in and around the GTA's networked enclaves was largely influenced by their housing trajectory. Home ownership is a desired outcome for the vast majority of newcomers in Canada (Simone \& Newbold, 2014) and is an important marker of spatial and temporal permanence and belonging (LungAmam, 2017). In this study, property ownership of singledetached homes was necessary to support the multigenerational living preferred by many participants, and the affordability of housing in the suburbs was a major draw to Peel Region. Yet, achieving home ownership was a challenge in an era of employment precarity and housing unaffordability that affects populations more broadly (Moos, Wilkin, Seasons, \& Chase, 2015; Worth, 2016). The reality of delayed home ownership slowed the settlement process for many newcomers and impacted a sense of belonging for immigrants like Raj:

I know I will be belonging when I get a job in my line [of work]....Then I can get a house, a good house for my children, and the parents. Then I will have BBQs and be Canadian.

The need for multi-generational housing and its impact on current growth-plans and sustainability priorities is an important consideration for planners working in an age of hyper-diversity, as this lifestyle deviates from that of the residents in past suburbs (Lung-Amam, 2017). However, there was considerable variety in the lifestyle of newcomers in this study that influenced their housing needs in the suburbs.

For many, like Raj, home ownership was often delayed or not possible in a climate of rising housing prices and increasing employment precarity. This meant a reliance on short-term and temporary housing options such as hotels, rental (and often crowded) apartments for years longer than expected. Further, the shortage of adequate housing also meant that plans for family reunification were delayed, which can have significant health and social impacts for newcomers like Raj (Dean \& Wilson, 2009). Other newcomers who arrived as a family unit or who were sponsored by family members who had already settled, had very different housing trajectories upon arriving. Their relative financial stability en- sured that they could make intentional decisions about whether to live in, near or outsider of an ethnic enclave.

Here we acknowledge that the individual settlement circumstances-arriving alone, arriving with family, ability to secure employment-are important nonrepresentational factors that influence the experiences of newcomers within and round ethnic enclaves. Theses housing trajectories and accompanying lifestyles become relevant to understanding social diversity in the suburbs when we use a hyper-diverse lens.

\section{Conclusions: A Hyper-Diversity Agenda in Planning}

This study contributes to the bodies of literature on social diversity in the suburbs and the growth of ethnic enclaves by addressing recent concerns about cultural pluralism in an era of increasing immigration. To date, scholarship on immigration, diversity and encountering difference has largely prioritized urban settings. This privileging of 'cosmopolis' as the reigning site of inter-ethnic and cultural encounter, negates the reality of growing cultural pluralism in the suburbs (Keil, 2018; Tyler, 2017). Suburbs are now the central site of immigrant hyperdiversity largely guided by new housing developments that attract immigrants, thus increasing the growth of ethnic enclaves (Qadeer et al., 2010). Much of the planning narrative on immigrant suburbanization has emphasized the 'threat' that emerging ethnoburbs pose to social cohesion, immigrant integration, and the very notion of national identity (Costa \& Kahn, 2003; Piekut \& Valentine, 2017; Pratsinakis et al., 2017; Putnam, 2007; Qadeer, 2016; Qadeer \& Agrawal, 2018; Tyler, 2017). In this article, we challenge the perception of homogeneity that has long plagued the suburbs, including the more recent emergence of ethnoburbs.

This study was exploratory and relied on perceptional and self-reported experiential data to shed light on the ways in which hyper-diversity influences life in suburban ethnic enclaves. As a qualitative study, it is not intended to be representative or generalizable to all immigrants in all suburban communities across the GTA. Rather, it has generated new ways of considering experiences in ethnic enclaves beyond ethno-cultural identity and practices, and highlights areas for future exploration. For instance, we did not ask participants to confirm their residence in an ethnic enclave, nor did we confirm their circumstances of immigration. Future research should examine residents' conceptualizations of ethnic enclaves and delve more deeply into the specific community features (e.g., population demographics versus built form) that attract hyper-diverse residents. Secondly, while participants discussed their mobility patterns and activity spaces between ethnic enclaves, we did not measure this directly. Mobile methodologies using personal GPS devices now allow researchers to track actual activity space, which is worth examining in the future to more systematically assess mobility within the fluid boundaries of ethnic enclaves in the GTA. Finally, our sample was limited to 
recent and mid-term immigrants. Future research should analyze the suburban experiences of those who migrated in childhood as well as second-generation immigrants in ethnic enclaves (see, Kataure \& Walton-Roberts, 2013) using the lens of hyper-diversity.

It is clear that immigration is now a suburban phenomenon, and one that is projected to continue in the future. Our findings conclude that there is a need for planning scholars and practitioners to critically assess the concept and construction of ethnic enclaves. Specifically, the use of arbitrarily defined categories of ethnicity to condense distinct populations does not acknowledge nor sustain social diversity. Rather, it creates false assumptions about who is leading parallel lives from whom, and inherently problematizes ethnic-minorities in enclaves for not mixing with the white majority. Concerns about social cohesion in an era of growing ethnic enclaves in the GTA perpetuates white-majority fears of being displaced and overrun by visible/ethnic/linguistic/religiousminority 'others' (Johnson, 2015; Lung-Amam, 2017). Particularly in the GTA where visible minorities now comprise the majority of the population, researchers and policy-makers must think about planning for ethnic diversity and social cohesion beyond the white versus nonwhite binary.

Sustaining social diversity in the suburbs requires that planning scholars and practitioners adopt the concept of hyper-diversity in order to think beyond the representational markers of difference, and towards nonrepresentational aspects of difference. This approach, in fact, is much more in line with what planners do best: plan for how people live (i.e., lifestyles and activities) rather than who they are (i.e., ethnic, religious, linguistic identities). Our findings promote three readings of hyper-diversity in Peel's suburbs that more aptly describe the differences in attitudes, behaviours, and lifestyles of recent immigrants. While these cannot be separated from participants' identity as visible/ethnic/linguistic/religious minorities in Canada, they provide alternative ways of understanding immigrants' agency. In particular, immigrants' interests in settling within the borders of an ethnic enclave were shaped by their sense of belonging, and their decision of where to live-within or outside an enclave-was the performance of that belonging. Secondly, the ability to perform for some ethnic-minority participants was made possible by the network of enclaves in the GTA, which shaped their mobility patterns. Finally, there was significant diversity in the migration and settlement experiences of participants which dramatically shaped their housing trajectory and settlement destinations.

This research provides evidence that challenges the assumption of the homogeneous ethnoburb by providing a broader understanding of what constitutes 'diversity' in the growing suburbs. Hyper-diversity is an emerging perspective globally and even more novel in the Canadian context but its potential for influencing the design of more inclusive suburbs is great.

\section{Acknowledgements}

We would like to thank the 115 newcomers who took time to share their stories. This project was funded by CERIS-The Ontario Metropolis Centre.

\section{Conflict of Interests}

The authors declare no conflict of interests.

\section{References}

Addie, J.-P. D., Fiedler, R. S., \& Keil, R. (2015). Cities on the edge: Emerging constellations in Canada. In P. Filion, M. Moos, \& T. Vinodrai (Eds.), Canadian cities in transition: Perspectives for an urban age (pp. 415-432). New York, NY: Oxford University Press.

Ahmed-Ullah, N. (2017, June 5). How Brampton, a town in southern Ontario was dubbed a ghetto. The Globe and Mail. Retrieved from www.theglobeandmail. com/news/toronto/brampton-a-story-of-political-im portance-power-and-ethnic-enclaves/article30273820

Alba, R., Logan, J., Stults, B., Marzan, G., \& Zhang, W. (1999). Immigrant groups in the suburbs: A reexamination of suburbanization and spatial assimilation. American Sociological Review, 64(3), 446-460. Retrieved from www.jstor.org/stable/2657495

Arthurson, K. (2012). Social mix and the city: Challenging the mixed communities consensus in housing and urban planning policies. Collingwood: CSIRO Publishing.

Bacqué, M., Fijalkow, Y., Launay, L., \& Vermeersch, S. (2011). Social mix policies in Paris: Discourses, policies and social effects. International Journal of Urban and Regional Research, 35(2), 256-273. https:// doi.org/10.1111/j.1468-2427.2010.00995.x

Bascaramurty, D. (2013, June 15). How Brampton demonstrates the new vision of Canada. The Globe and Mail. Retrieved from www.theglobeandmail.com/ news/national/how-brampton-demonstrates-the-new -vision-of-canada/article12581170

Brenner, N. (2014). Implosions/explosions. Towards a study of planetary urbanization. Berlin: Jovis.

Castles, S., de Haas, H., \& Miller, M. J. (2013). The age of migration: International population movements in the modern world. London: Macmillan International Higher Education.

Corbin, J., \& Strauss, A. L. (2014). Basics of qualitative research: Techniques and procedures for developing grounded theory (4th ed.). Los Angeles, CA: Sage Publications.

Costa, D., \& Kahn, M. (2003). Civic engagement and community heterogeneity: An economist's perspective. Perspectives on Politics, 1(1), 103-111. https://doi.org/10.1017/S1537592703000082

Dean, J. A., \& Wilson, K. (2009). 'Education? It is irrelevant to my job now. It makes me very depressed...': Exploring the health impacts of under/unemploy- 
ment among highly skilled recent immigrants in Canada. Ethnicity \& Health, 14(2), 185-204.

Fava, S. F. (1956). Suburbanism as a way of life. American Sociological Review, 21(1), 34-37.

Forsyth, A. (2012). Defining suburbs. Journal of Planning Literature, 27(3), 270-281. https://doi.org/10.1177/ 0885412212448101

Ghosh, S. (2013). 'Am I a South Asian, really?' Constructing 'South Asians' in Canada and being South Asian in Toronto. South Asian Diaspora, 5(1), 35-55.

Graham, S., \& Healey, P. (1999). Relational concepts of space and place: Issues for planning theory and practice. European Planning Studies, 7(5), 623-646.

Grewal, S. (2013, May 24). Brampton suffers identity crisis as newcomers swell city's population. The Toronto Star. Retrieved from www.thestar.com/ news/gta/2013/05/24/brampton_suffers_identity_ crisis_as_newcomers_swell_citys_population.html

Hanlon, B. F., Vicino, T. J., \& Short, J. R. (2006). The new metropolitan reality in the US: Rethinking the traditional model. Urban Studies, 43(12), 2129-2143.

Harris, R. (2015). Using Toronto to explore three suburban stereotypes, and vice versa. Environment and Planning A, 47(1), 30-49.

Hiebert, D., Schuurman, N., \& Smith, H. (2007). Multiculturalism "on the ground": The social geography of immigrant and visible minority populations in Montreal, Toronto and Vancouver, projected to 2017 (Working Paper Series no. 07-12). Vancouver: Metropolis British Columbia Centre of Excellence for Research on Immigration and Settlement.

Johnson, M. (2015). The new Bostonians: How immigrants have transformed the Metro Area since the 1960s. Amherst, MA: University of Massachusetts Press.

Johnston, R., Gendall, P., Trlin, A., \& Spoonley, P. (2010). Immigration, multiculturalism and geography: Intergroup contact and attitudes to immigrants and cultural diversity in New Zealand. Asian and Pacific Migration Journal, 19(3), 343-369.

Kataure, V., \& Walton-Roberts, M. (2013). The housing preferences and location choices of secondgeneration South Asians living in ethnic enclaves. South Asian Diaspora, 5(1), 57-76.

Keil, R. (2018). Extended urbanization, "disjunct fragments" and global suburbanisms. Environment and Planning D: Society and Space, 36(3), 494-511. https://doi.org/10.1177/0263775817749594

Kraftl, P., Bolt, G., \& Van Kempen, R. (2018). Hyperdiversity in/and geographies of childhood and youth. Social \& Cultural Geography, 18(8), 1-9. https:// doi.org/10.1080/14649365.2018.1491619

Li, W. (1998). Anatomy of a new ethnic settlement: The chinese ethnoburb in Los Angeles. Urban Studies, 35(3), 479-501. https://doi.org/10.1080/ 0042098984871

Li, W. (2005). Beyond chinatown, beyond enclave: Reconceptualizing contemporary chinese settle- ments in the United States. GeoJournal, 64(1), 31-40. https://doi.org/10.1007/s10708-005-3921-6

Li, W. (2009). Ethnoburb: The new ethnic community in urban America. Hawai: University of Hawai'i Press.

Lung-Amam, W. S. (2017). Tresspassers? Asian americans and the battle for suburbia. Oakland, CA: University of California Press.

Moos, M., Wilkin, T., Seasons, M., \& Chase, G. (2015). Planning for housing in a time of growing employment precarity. Plan Canada, Spring, 12-17.

Omidvar, R., \& Richmond, T. (2003). Immigrant settlement and social inclusion in Canada. Toronto: Laidlaw Foundation.

Park, R. E., Burgess, E. W., \& McKenzie, R. D. (1925). The city. Chicago, IL: University of Chicago Press.

Peterson, M. (2017). Living with difference in hyperdiverse areas: How important are encounters in semipublic spaces? Social \& Cultural Geography, 18(8), 1067-1085.

Piekut, A., \& Valentine, G. (2017). Spaces of encounter and attitudes towards difference: A comparative study of two European cities. Social Science Research, 62, 175-188.

Pitter, J., \& Lorinc, J. (Eds.). (2016). Subdivided: Citybuilding in an age of hyper-diversity. Toronto: Coach House Books.

Pratsinakis, M., Hatziprokopiou, P., Labrianidis, L., \& Vogiatzis, N. (2017). Living together in multi-ethnic cities: People of migrant background, their interethnic friendships and the neighbourhood. Urban Studies, 54(1), 102-118. https://doi.org/10.1177/ 0042098015615756

Putnam, R. D. (2007). E pluribus unum: Diversity and community in the twenty-first century the 2006 Johan Skytte Prize lecture. Scandinavian Political Studies, 30(2), 137-174. https://doi.org/10.1111/j.14679477.2007.00176.x

Qadeer, M. (2016). Multicultural cities: Toronto, New York, and Los Angeles. Toronto: University of Toronto Press.

Qadeer, M., \& Agrawal, S. (2018). Adjusting to Toronto's new reality. Plan Canada, Summer, 40-42.

Qadeer, M., Agrawal, S., \& Lovell, A. (2010). Evolution of ethnic enclaves in the Toronto Metropolitan Area 2001-2006. Journal of International Migration and Integration, 11(3), 315-339. https://doi.org/ 10.1007/s12134-010-0142-8

Qadeer, M., \& Kumar, S. (2006). Ethnic enclaves and social cohesion. Canadian Journal of Urban Research, 15(2), 1-17. Retrieved from www.jstor.org/stable/ 26192499

Sandercock, L. (2003). Planning in the ethno-culturally diverse city: A comment. Planning Theory \& Practice, 4(3), 319-323. https://doi.org/10.1080/ 1464935032000118661

Sandercock, L. (2004). Towards a planning imagination for the 21st century. Journal of the American Planning Association, 70(2), 133-141. https://doi.org/ 


\section{$10.1080 / 01944360408976368$}

Simone, D., \& Newbold, K. B. (2014). Housing trajectories across the urban hierarchy: Analysis of the longitudinal survey of immigrants to Canada, 2001-2005. Housing Studies, 29(8), 1096-1116.

Singer, A., Hardwick, S. W., \& Brettell, C. B. (2008). Twenty-first century gateways: Immigrant incorporation in suburban America. Washington, DC: Brookings Institution Press.

Statistics Canada. (2017a). Census Profile, 2016 Census (Catalogue no. 98-316-X2016001). Ottawa: Statistics Canada. Retrieved from www12.statcan.gc.ca/ census-recensement/2016/dp-pd/prof/index.cfm? Lang $=\mathrm{E}$

Statistics Canada. (2017b). Population growth: Migratory increase overtakes natural increase. Ottawa: Statistics Canada. Retrieved from www.statcan.gc. ca/pub/11-630-x/11-630-x2014001-eng.htm

Talen, E. (2008). Design for diversity: Exploring socially mixed neighbourhoods. London: Architectural Press.

Tasan-Kok, T., van Kempen, R., Raco, M., \& Bolt, G. (2014). Towards hyper-diversified European cities: A critical literature review. Utrecht: Utrecht University.

Tyler, K. (2017). The suburban paradox of conviviality and racism in postcolonial Britain. Journal of Ethnic and Migration Studies, 43(11), 1890-1906. https://doi.org/10.1080/1369183X.2016.1245607

Tzaninis, Y., \& Boterman, W. (2018). Beyond the urbansuburban dichotomy. City, 22(1), 43-62. https:// doi.org/10.1080/13604813.2018.1432143

Van de Ven, A. H. (2007). Engaged scholarship: A guide for organizational and social research. New York, NY: Oxford University Press.

Vertovec, S. (2007). Super-diversity and its implications. Ethnic and Racial Studies, 30(6), 1024-1054.

Vicino, T. J. (2013). Suburban crossroads: The fight for local control of immigration policy. Lanham, MD: Lexington Books.

Walks, A. (2013). Suburbanism as a way of life, slight return. Urban Studies, 50(8), 1471-1488. https:// doi.org/10.1177/0042098012462610

Werbner, P. (2013). Everyday multiculturalism: Theorising the difference between 'intersectionality' and 'multiple identities'. Ethnicities, 13(4), 401-419. https://doi.org/10.1177/1468796813483728

Wilkinson, S. (2018). Young people's drinking spaces and $\mathrm{im} /$ mobilities: A case of 'hyper-diversity'? Journal of Youth Studies, 21(6), 799-815.

Wilson, J. H., \& Singer, A. (2011). Immigrants in 2010 Metropolitan America: A decade of change (Metropolitan Policy Program). Washington, DC: Brookings. Retrieved from www.brookings.edu/wpcontent/uploads/2016/06/1013_immigration_wilson _singer.pdf

Worth, N. (2016). Feeling precarious: Millennial women and work. Environment and Planning D: Society and Space, 34(4), 601-616.

\section{About the Authors}
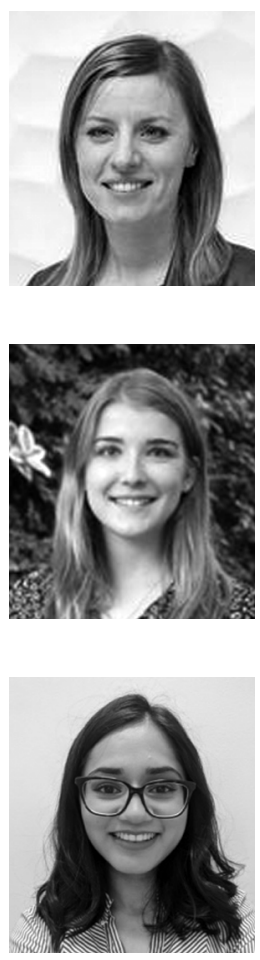

Jennifer Dean (PhD) is an Assistant Professor in the School of Planning at the University of Waterloo. Trained as a social and health geographer, Dr. Dean conducts research on the broad connections between place and health with specific attention to the social determinants of health including social inclusion and belonging. She has worked with newcomer populations in Peel for over a decade to better understand how their temporal experiences and interactions with local environments impact health and well-being.

Kristen Regier is a student researcher at the University of Waterloo where she is currently researching the health impacts of rural settlement on immigrants in Peel Region. She is also a Bachelors' candidate in the School of Planning at the University of Waterloo. Ms. Regier is planning on attending graduate school next fall and is especially interested in research involving sustainable design, equity, and diversity.

Asiya Patel is a Research Assistant and candidate for a Bachelor of Environmental Studies at the University of Waterloo in the School of Planning. Her interests are in the areas of tangible and intangible cultural heritage, in addition to equitable community planning and design. For Ms. Patel, a grounded understanding of the intersectionality of the human experience is a rewarding scholarly pursuit. 


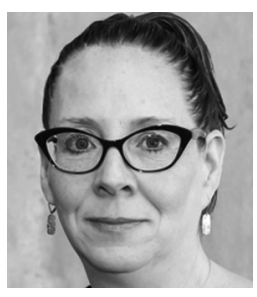

Kathi Wilson (PhD) is a Professor in the Department of Geography and Acting Vice-Dean (Faculty) at the University of Toronto Mississauga. Dr. Wilson's research focuses on understanding the links between health and place. She is particularly interested in examining inequalities in health and access to health care as they pertain to newcomer and Indigenous populations.

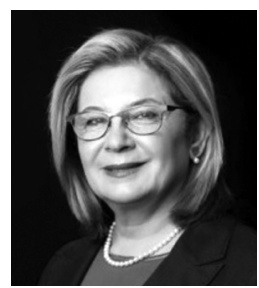

Effat Ghassemi is the founding Executive Director of the Newcomer Centre of Peel for the past two decades. She obtained her Master's degree in Immigration and Settlement Studies from Ryerson University and has continued her education at the PhD level in Family Relations and Human Development University of Guelph. Ms. Ghassemi has been a tireless advocate for successful resettlement and integration of newcomers to Canada and is dedicated to building a community of diverse leaders who see prosperity in immigration. 